\title{
ÉLÖ NYELV
}

\section{Nyelvünk táji változatosságának dicsérete*}

1. A fordulat nem most és nem egyszerre következett be. Már jó néhány évtizede biztató jeleit láthatjuk annak, hogy változik a megítélése a nyelv belső változatosságának, a táji változatosságnak. Ma már talán nemcsak a nyelvészek körében tűnne naivnak az a kérdés, ami korábban kézikönyvekben is közkeletü volt, hogy hogyan keletkeztek a nyelvjárások. Nyilvánvaló, hogy „kezdetben vala a nyelvjárás”, a nyelvjárás maga volt a nyelv. És legtöbbünk számára - Heideggert parafrazálva - személyes létünk első otthona is a nyelvjárás volt. Feltehetően az anyanyelv-pedagógia, az oktatás is másképpen viszonyul a nyelvjárásban beszélő tanulókhoz, mint Illyés Gyula gyermekkorában. A mai világban a nyelvjárások már nem távoli egzotikumok: a különböző vidékek lakói gyakran kerülnek kapcsolatba egymással, a rádióban, a televízióban is hallhatják, láthatják egymást. Tapasztalhatják a beszéd természetes változatosságát. A nyelvészek, a dialektológusok, a névkutatók munkája is meghozta a gyümölcsét: atlaszok, helynévtárak, új tájszótár, korszerü kézikönyv, digitális feldolgozás és megjelenítés segíti az eligazodást. Erdélyre vonatkozóan félszázados erőfeszítések eredményeként elkészült és megjelent a két alapmunka: a nyelvjárás-történetinek tekinthető Erdélyi magyar szótörténeti tár tizennégy és A romániai magyar nyelvjárások atlasza tizenegy kötete. Mindkettőben fontos volt az anyaországi támogatás, az erdélyi és a budapesti nyelvészek szakmai együttmüködése.

Ezt a megváltozott szemléletet erősíti meg most A Magyar Nyelv Napja ünnepi rendezvénye. Ez a nap - mint köztudomású - a magyar nyelvet hivatalossá tevő törvény, az 1844. évi II. törvénycikk elfogadásának napja. Éppen 170 esztendeje történt, mérföldkő volt a magyar nyelv fölemelkedésében. Az viszont kevésbé tudott, és én is csak jó okkal feltételezem, hogy ennek az utólag is sokak által kárhoztatott törvénynek az előkészítésében nyelvészként és az Akadémia elnökeként döntő szerepe volt gróf Teleki Józsefnek. Ehhez elég elolvasni az egy évvel korábban az Akadémia közgyülésén elmondott elnöki beszédét. Nem állhatom meg, hogy ne idézzem ifjúkori nyelvészeti munkájában kifejtett véleményét a nyelvjárásokról és a nyelvjárási beszélők nyelvi leleményéről: „mert valamint az egész nemzetnek vagyon hatalma a maga nyelvét mívelni, éppen úgy vagyon minden egyes vidéknek is." (A magyar nyelvnek tökéletesítése új szavak és szólásmódok által. 1816/1988. ÉDER ZOLTÁN gondozásában, előszavával. Szépirodalmi könyvkiadó, Budapest, 252). Majd a továbbiakban: „A sokféle szőrszálhasogató vizsgálódásokkal meg nem romlott, eredeti erővel felruházott, együgyü emberi elme az új képzetek helyes kifejezéseinek eltalálásában gyakran sokkal szerencsésebb, mint a félénk nyelvtudós, ki nyelvét megrontani minduntalan rettegvén, az erősebb, hathatósabb kifejezésekhez nyúlni nem mer.” (i. m. 254).

„Kezdetben vala a nyelvjárás” - a szóbeliségben mindenképpen, de az írásbeliség kezdeti időszakában és még a könyvnyomtatás indulásakor is. Ez ma nem annyira nyilvánvaló, mivel az oktatásnak és a nagyközönségnek szánt szövegkiadások rendszerint

* Előadásként elhangzott 2014. november 13-án, a Magyar Nyelv Napján, az Anyanyelvápolók Szövetsége ünnepi rendezvényén a Petőfi Irodalmi Múzeumban.

DOI: 10.18349/MagyarNyelv.2015.1.75 
éppen a korai szövegek nyelvjárásiasságát tüntetik el. De a látszat ellenére: nem maga a nyelv szabályozott (fóképpen írott) változata szorította háttérbe, és hozta rossz hírbe a nyelvjárásokat, hanem a nyelvi ideológiák. Azok a nyelvi ideológiák, amelyek rendszerint együtt kárhoztatják az országon belüli többnyelvüséget és a nyelven belüli táji sokféleséget, és amelyek úgy láttatják, hogy a dialektusok a nyelv romlott, korcs helyi változatai. Európában erre sok példát lehetne idézni, mindenekelött a franciát, közelünkben a románt. Lenézettség, müveletlenség, iskolázatlanság, helytelen nyelvhasználat - ez társult a nyelvjárási beszédhez, ahhoz, aki nyelvjárásban beszélt.

A nyelvi mozgás újkori összetartó irányát nehéz volna tagadni, de semmi nem indokolta azt, hogy az egységesülést a fejlödés jelének és kötelező irányának tekintsék. Az elmúlt hetekben újra elolvastam LÖRINCZE LAJOS legfontosabb szövegeit az 50-es, 60-as évekből. Érezhetően belső feszültségekkel élte meg annak az ideológiai parancsnak a ,teljesítését”, amely a nyelv esetében is megkívánta a folyamatos, sőt gyors fe j 1 ö d é s t, és ezt elsősorban az egységesítésben kívánta megvalósítani. Akkoriban minden „fejlödött”, és ebből a nyelv sem maradhatott ki. Kissé orwelli hangulata volt ennek az eszmének: a központi normának, az egyetlen normatív változatnak, annak, hogy a nyelvjárások ilyen értelemben akadályai a fejlődésnek. Lőrincze tanár úrnak minden nyelvi élménye, tudása ezzel ellentétes volt, és ebben Kodály Zoltán tekintélyére hivatkozhatott, támaszkodhatott. A nyelvmüvelés gyakorlatában mérlegelték a nyelvjárási jelenségeket: melyek milyen mértékben szalonképesek, hogyan minősíthetők ,a norma” szempontjából. Ez a mérlegelés éppen a legjellemzőbb jelenség, a kétféle $e$ hang megítélésében volt a legbizonytalanabb. Lőrincze tanár urat közvetlenül, személyesen is érintette ez a vita, hiszen az $\ddot{e}$ saját beszédének is jellemző színe volt, ő is olyan környezetben született - a magyar anyanyelvüek többségéhez hasonlóan -, ahol a nyelv csak ezzel a hanggal volt igazán érthető. Most mégis arról kellett volna határozott véleményt mondani, melyik felel meg a köznyelvi normának, mi a norma ebben a tekintetben. A norma azonban itt megbicsaklott: ha az ë köznyelvi, megfelel a normának, akkor az ezt nem használók helytelenül beszélnek, és fordítva: az $\ddot{e}$ használata helytelen. Ezt így senki nem merte kimondani, és miközben attól tartottak, hogy megbélyegzik az egy $e$-vel beszélőket, ennek az ellenkezője történt. A nyilvánosság mintaadó nyelvhasználatából, a hivatásos beszélők (bemondók, színészek) nyelvéböl az ë szorult ki szinte teljesen.

Azt hiszem, hogy már túlléptünk ezen, és nem az egyetlen normához viszonyított helyes vagy helytelen végleteiben gondolkodunk, hanem a nyelvjárások, nyelvi regiszterek saját normáihoz viszonyított helyénvalóságban. És nem az elhatárolásban, hanem a változatosság és változás folyamatosságában. Ez a heterogén harmónia a nyelv igazi egysége. Ebben a keretben a nyelvjárás teljes értékü nyelvváltozat, a teljes élet kifejezője adott közösségben. Némely jelenségeiben nagyon konzervatív, és mégis változó. Önálló, de nem elkülönülő rendszer, amelynek kifejezési lehetőségei (kifejező erő, szabályszerüség, logikusság, árnyaltság, komplexitás stb.) ugyanolyanok, mint a köznyelvéi. Nem tekinthető puszta stiláris változatnak, nem a nyelv egy alsóbb szintje, hanem stilisztikailag maga is differenciált. El lehetne-e vitatni a költőiséget, a stiláris kidolgozottságot a népdaloktól, általában a népköltészet, a hagyomány ritualizált szövegeitöl?

2. Máris elérkeztem a címben jelölt témához: a táji változatosság dicséretéhez. Ez az én esetemben hazabeszélés, a végek dicsérete. Mégsem szeretném, ha úgy tűnne, mintha 
csak az erdélyi és a székely mítoszát vagy a csángóként mitizált moldvai magyar nimbuszát szeretném itt erősíteni. Az életem, a munkám elsősorban Erdélyhez köt ugyan, a példáim is innen származnak, de a nyelvjárási színek, értékek ott vannak nyugaton, északon és délen is. Érthetően kevésbé a nyelvterület közepén.

A nyelvjárásokban benne van a nyelv története. Néha ahány kilométer térben a központtól, szinte annyi esztendő visszafelé az időben. Sok minden megvan saját nyelvjárásomban, a kalotaszegiben is. Amikor az igeragozás történetét tanultam az egyetemen, elég volt felidézni az otthon még mindennapos íra, irá, írt volt, íra vala igealakokat, hasonlóképpen a névragozásban a papni, papnul, a lovok és a szomszédfalubeli lovik-ot. De mindez eltörpül a legarchaikusabb magyar nyelvjárás, a moldvai mellett, amellyel mostanában foglalkozom. Egyik része, a legarchaikusabb, a közép-erdélyi Mezőség középkori reliktuma, másik része a székely két-három évszázados előképe. Csak a szavakból szemelgetek: az asszony, a nő és a feleség(em) legrégebbi megnevezése: nép níp, népem nípem, és ez megerösíti azt, a TESz.-ben csak feltételezésként megfogalmazott véleményt, hogy a nép etimológiailag összefügg a nő szóval. Az após és az anyós régi neve: ipa és napa, az idősebb sógoré a lér (a lat. levir emlékeként). A sír(ik) mellett használatos még a rí, riu. Annyëkot sirok, s annyëkot busulok, hogy sokszor nem ës látom a zutat mondja egy lészpedi asszony. Kifejezésként Szabófalváról: rivu a szüve 'szomorú' jelentésben. A fáj(ik) mellett még ott a sérik (mai köznyelvünkben már csak származékai: sért, sérül). Szabófalváról: Eszik szebësszéget (= savanyúságot), sziérik a hasza, Jugánból: Ha szérik a szüved, kell mondzs valamit. Máskor mai szavaink konkrétabb jelentésével találkozunk: kedves az, akinek jókedve van: Egy kicsit kedveske votam, mert ittam ëgy kicsi pálinkát (Berzunc), az archaikus moldvaiban, aki engesztel, még zsírt engesztel, azaz 'olvaszt', és így a zsír engesztelődik, nem az ember. De olyan, távoli tárgyi emlékek sem hiányoznak ebből a nyelvi világból, mint az ördegjáram: az ágaival hálószerüen alakított, összefontan növesztett élőfa, amely maga volt az élő akadály, az élő kerítés; a nádméz, amely mai 'cukor' jelentésében is még azért nádméz, mert azzal a mézzel édesítettek, amelyet a nádfedél szálaiba a darazsak gyüjtöttek.

Ezek a nyelvi régészet részben még élő emlékei. A mai változatosság, a változatosság szépsége nem ebben érzékelhető, nem ebben élvezhető. Sokkal inkább és mindenekelőtt a hangzásban: az $\ddot{e} \sim e \sim \ddot{o}$, az $o ́ \sim o^{u}, \ddot{o} \sim \ddot{o}^{\ddot{u}}$, azé $\sim \dot{i}$, a rövid hosszú váltakozásban, és bizonyára leginkább az intonációban. Néhány évtized alatt is sokat változott a (városi) köznyelv és a (falusi) nyelvjárás és a kettő viszonya, de nem oly sokat, hogy ne idézhetnénk ma is Kodály Zoltán emelkedett sorait: „A városi beszélő ajkán kopog a nyelv, mint a Morse-távíró. A falusiak ajkán zeng, omlik, mint az orgonaszó. A városi ritmusa bizonytalan, ingadozó, a falusiaké acélos, rugalmas, törhetetlen. A városi hanghordozása tétova, nem mindig jellegzetes, néha idegenszerű: a falusiaké kristályos, tévedhetetlen. Minden hang a maga helyén, másképp nem is lehetne. Érezzük: ezt a beszédmódot követeli a nyelv természete, minden sajátsága. Így hangzik a legszebben." (Magyar zene, magyar nyelv, magyar vers. Szépirodalmi Kiadó, Budapest, 1993. 307.) Valóban így van-e? A peremnyelvjárásokban és a szórványokban a kétnyelvüségnek ebben legközvetlenebbek a következményei: időtartam, hangsúly, intonáció, írásban is az ezt tükröző szórend egyre inkább a domináns nyelvnek a magyarétól teljesen eltérő mintáit követi. És a beszélők erre érzékenyek a legkevésbé. 
A ritkán emotív köznyelvhez viszonyítva a nyelvjárásokban erőteljesebben érvényesül az érzelemkifejezés közvetlensége és intenzitása: a beszéd tempójában, a hangerő, a hangsúly és a beszéddallam szélsőségeiben és hullámzásában, az arcjátékban, a gesztusban, a testnyelv sokféle megnyilvánulásában. Gyakran nyelvileg is nagyon láttatóan kifejezve: Addig sirtam, hogy árkot vert az arcámon a könnyü (Klézse); buszultak a zorcáji szomorú volt az arca (Ploszkucény). De a szókincsben is: hangutánzó és hangfestő szavakban, kicsinyítő és becéző származékokban. A tekenőben vizet pacskoló, lubickoló gyermek a székelyben: csepcsel, lepcsel, fecsel, fecsegtet, habuckol, hintez, licskol, locsál, locskol, priccol, prickol, pereckel (csak felnőttként lepődtem meg azon, hogy mi a zabál igét használtuk ilyen értelemben); a szitáló eső: csepeg, csepereg, csepeget, harmatoz, permel, permetez, perméz, pesztereg, petyeg, petyereg, pezderjézik, szitálgat, szöszmötél.

A nyelvjárás - noha konzervatív - nem leülepedett rendszer. Különösen szókincsében, kifejezéseiben nem. Bizonyára nem egyforma mértékben, de éppen a teremtő erő, a fokozott kreativitás és az ezzel többnyire összefüggő képszerü láttatás jellemezhet egyegy táji nyelvváltozatot. A helyi nyelvi kreativitás erőteljesen mutatkozott meg az újvilági növények, a bab, a burgonya, a kukorica, a napraforgó megjelenésekor, terjedésekor. Meg kellett nevezni őket, és ennek meg is találta a módját mindegyik vidék. A fokozott kreativitás ma néha a szorult nyelvi helyzetben lévő beszélő kreativitása. A moldvaiak kedves nyelvi leleményei a 'kullancs' jelentésü buvóka, a katicabogár neveként a melegeresztö, a koldus neveként a kapogató. A növény- és állatnevek körében különösen gyakori a metafora. Erdélyi példák: barátkása 'kankalin', istengyümölcs 'galagonya', leánkamadár 'barázdabillegetö', disznószöcs 'sündisznó', kígyópásztor 'szitakötő'. Ez utóbbi a székelyben és a nyugati nyelvjárásban is ismert, és szláv párhuzamai is vannak. (A metafora néha éppen egy másik nyelvből származik.) Szimbolikusként is értelmezhetök az élet szó olyan jelentései, mint 'a beépített telek, a család ősi, örökölt telke' vagy az ismertebb 'kenyérgabona’ jelentés. Feltételezhető párhuzamosság van egy nyelvjárás metaforizáló hajlama és a helyi kultúra szimbolizáló ereje között. Ez az erő, ez a képszerüség anyanyelvjárásuk révén gyakran közvetlenül sugárzik át írók, költők művészi nyelvébe.

A népi bölcsesség nyelvi példáit nagy számban tartalmazzák frazeológiai gyüjteményeink. Azt gondolhatnánk, hogy ezek szintén csak a múlt emlékei, jó, hogy már a régi gyüjtők, Kriza János és mások lejegyezték őket. De az ember ma is tanúja lehet szellemes élcelődésnek, okos érvelésnek. Elhangzik egy vélemény, és mindjárt rá a népi dialektika: A fészinek foka is van, éle is, és következnek az ellenérvek, a dolgok másik oldalának megvilágítása. A moldvaiból való ez a figyelmeztető bölcsesség: Ez erdőnek vagya(n) filye, sze mezőnek szeme, ti. ha valaki fát lop, az erdőben a fejszecsapások hallatszanak, a mezőn pedig meglátják a tolvajt. Szintén onnan ered, a románnal is közös a fejszenyél mint az áruló metaforája ebben a közmondásban: Ez erdö nem feél e fészétöl, ha ni(n)csen nyele a fejsze nyele is fából készült, tehát áruló; nem kell félni az olyan ellenségtől, amely nem vásárolt meg egy árulót.

3. Úgy tünhet, és lehet, úgy is van, hogy egyik túlzásból a másikba estem. Én ugyanis túlzónak tartom azt a sztereotípiát, hogy táji változatok már nincsenek, vagy alig vannak. Azt is, amit a kutatók pánikszerüen a 24. órának éreznek. Alapvetően torzító a perspektívánk, a beszélők perspektívája általában. Jól ismert tapasztalat a nyelvjárási gyüjtőmunkában, hogy első lépésben mindig a szomszédhoz, másokhoz irányítják a kutatót, merthogy ők nem beszélnek nyelvjárásban. Ennek oka saját nyelvhasználatunk megszokottsága, va- 
lamint a nyelvjárási beszédmód lenézettsége, és néha az ebből táplálkozó szégyenérzet. A nyelvészetben és még inkább a köztudatban is van egy ilyen hamis perspektíva. Úgy vagyunk vele, mint a régi nagy telek nosztalgiájával: városi környezetben azt hisszük, nincsenek már igazi telek. De ha visszamegyünk gyermekkorunk színhelyére, még sok mindent megtalálhatunk régi telek hangulatából és első nyelvünk hangjaiból, ízeiből.

A peremhelyzet, az elszigeteltség a külső régiókban inkább megőrizte a táji változatokat. De nemcsak megőrződtek a nyelvjárások, hanem föl is értékelődtek. A helyzet folytán a közös változat szorult háttérbe: az előző században a politikai státus változásával leszükültek az irodalmi nyelvet és a köznyelvet erősítő oktatás lehetőségei és a használat alkalmai. Ez a változás kevésbé vagy egyáltalán nem érintette a nyelvjárásokat. Megnőtt a használati értékük, és fokozódott a szerepük a veszélyeztetetté, védekezővé vált identitásban. Általánosabb szinten a nemzeti azonosságtudat alapvető, közös eleme a magyar nyelv, a standarddal és minden változatával együtt. A nyelvjárásoknak a lokális, a helyi és a regionális identitásban van hasonló szerepük. Akik a helyi nyelvjárást beszélik, ezzel azt is jelzik, hogy közösségként összetartoznak, a beszélö pedig azt, hogy azonosul ezzel a közösséggel. Számukra ez jelenti a nyelvi otthonosságot.

Mindebböl azt lehetne érteni, hogy kívül az országhatáron meg lehet élni anyanyelvünk közös változata nélkül. Ez az élet - ha kényszerhelyzetben van is rá példa - nem teljes élet, bizonytalan nyelvi sorsában is. Jól ismert annak az aszimmetrikus kétnyelvüségi formának a törékeny volta, amelyben a beszélő anyanyelvét csak beszélni tudja annak vernakuláris változatában, írni nem tanul meg, a második nyelvet viszont írott, közös változatában is elsajátítja. Ez az anyanyelv szempontjából előnytelen helyzet szinte törvényszerüen vezet el a nyelvcseréhez. Ilyen helyzetben a stabilitást éppen nyelvünk közös változata biztosítja, azt a kétnyelvüséget, amelyben az anyanyelv a maga teljességében van jelen, mindig magasabb szinten, mint a második nyelv. Ez indokolja mindenekelött az oktatásban az anyanyelv elsődlegességét. Ez és a korábbi szétfejlödés utáni nyelvi közeledés eredményezi már most is az iskolázott fiatalok természetes mozgását a helyi és a közös nyelvváltozat kontinuumán. Az más kérdés, hogy a standard erdélyi, felvidéki, vajdasági, kárpátaljai változata sem teljesen azonos a budapestivel. Nem is kell annak lennie.

Mi történik azokkal, akik a perem- és maradékszórványokban, a nagyvárosi lakótelepek államnyelvi környezetében beszélik ugyan anyanyelvük lenézett helyi változatát, múvelt, írott változatként azonban a jogilag is magasabb rangú románt, szlovákot, szerbet, ukránt, szlovént sajátítják el, szakmát is ezen tanulnak? Ennek perspektíváját jól példázza a moldvai magyarok sorsa. Az ő kétnyelvüségük a két nyelv kiegyensúlyozott szóbeliségében, a helyi nyelvjárásban évszázadokon át fennmaradhatott, amikor azonban az egyik nyelv jogi státusában és standardként a másik fölé emelkedett, megállíthatatlanná vált a nyelvcsere. Ez történik az egyéni kétnyelvüséggel is, ha abban hasonló módon billen meg az egyensúly. A nyelvcserében utolsóként az anyanyelvjárási változat tünik el. Hosszabb ideig megőrződhetnek - anélkül, hogy használóik értenék őket - a rituálizált reliktumszövegek: imádságok, népdalok, állandó szókapcsolatok. Ilyen értelemben az is elmondható, hogy nemcsak „kezdetben vala a nyelvjárás”, de a beszélő - utolsó közösségi kötelékeként, korábbi azonosságának utolsó jegyeként is - a maga nyelvjárásában marad meg, ameddig megmarad.

PÉNTEK JÁNOS

Babeş-Bolyai Tudományegyetem 